\title{
The Dysfunctional and Functional Effect of Celebrity Endorsement on Brand Patronage
}

\author{
Okorie Nelson, Covenant University, Nigeria \\ Oyedepo Tunji, Covenant University, Nigeria \\ Akhidenor Gloria, University of Lagos, Nigeria
}

\begin{abstract}
The ever increasing brand multiplicity and competition on the market of goods and services have dictated the pace of growth in the usage of celebrity endorsement across the globe. The use of celebrity endorsement has become a prime brand communication strategy in organizational management that aids the sale and promotion of brands across the globe. It is a popular approach in marketing communication for all brand management. This paper examines celebrity endorsement as a brand communication tool that serves as an aid to expedite brand image and purchase. However, it can also become horrific unless accompanied by a powerful idea, effective and impeccable positioning.
\end{abstract}

Keywords: celebrity endorsement, brand, purchase and dysfunctional effect 


\section{Introduction}

The intense usage of celebrity endorsement as a tool of advertising strategy has increased drastically in the past few years; celebrities have been used to promote various kinds of products and services, from sports to beverages to all kinds of electronics and several other products. The drastic rise of celebrity endorsers is not limited to a specific sector of the economy, companies using celebrity endorsement cut across all industry categories including packaged goods, telecommunication, financial services and automobile industries (Thompson, 1998, Okorie, 2010; Okorie \& Aderogba, 2011). In the United States, $25 \%$ of all advertisements in newspapers and magazines employ the use of endorsers (White, 2000). In essence, these measures suggest that many US firms have bought into the hypothesis that celebrity endorsers positively impact consumers' attitude to an associated brand (Ohanian, 1991; Okorie \& Aderogba, 2011).

The significance of celebrity endorsers in brand communication strategies does not only recline in the fact that they are used by firms who wish to increase income, but in how these celebrities add value to a company, brand or product. Amos, Holmes \& Strutton (2008) have also observed that celebrity endorsement is more likely to be observed for those products having a high price-production cost margin and on a large customer base. In other words, celebrity endorsements are more emblematic for nationally marketed products then for local or niche market products and for products. Conglomerates invest huge amounts of money to draw parallels between its products and a celebrity in the belief that it would help attract attention to the products/services endorsed and help transfer the image values of the products/services through the fame of a celebrity (Meenaghan and O"Mahony, 1998).

This paper examined the association between endorsements and brand there by identifying the functional and dysfunctional effects related to this strategy. Also, the model of meaning transfer, the match up hypothesis and source credibility would serve as theoretical constructs to discuss the relationship between celebrities and the brands they endorse. 


\section{Theoretical Constructs of Celebrity Endorsement}

On the application and practice of celebrity endorsement, there are several models and concepts that explain the underlying function and importance of celebrity endorsement. In this paper, source credibility, transfer of meaning model and the match up hypothesis were used to discuss the nature and use of celebrity endorsement

1. Source Credibility: Source credibility suggests that the effectiveness of a message depends on the "expertness" and "trustworthiness" of the source (Hovland, Janis, and Kelley, 1953; Sternthal, Dholakia, and Leavitt 1978). The central goal of advertising is the persuasion of customers i.e., the active attempt to change a modify consumers attitude towards the brands (Soloman, 2002). Hence, in order to convince the target audience of the attractiveness of the company's brand. The creditability of the advertisement is immense.

Researchers and scholars in marketing communication have identified three components as making up the credibility construct: knowledge or expertise, trustworthiness, and appearance or attractiveness (Baker and Churchill, 1977; Joseph, 1982; Kahle and Homer, 1985; Maddox and Rogers, 1980). Attempts to measure the impact credibility on consumers' intentions to purchase indicate that only "expertise" had any significant influence on intentions to purchase. There also seems to be a direct correlation between believability and overall advertisement effectiveness, as measured by purchase intentions (Kamins, Brand, Hoeke, and Moe, 1989).

2. Transfer of meaning model: McCracken (1989) has reasoned that the meaning transfer model is based on the effectiveness of the endorser depends on the meaning the celebrity is bringing into the endorsements process and the brand. Celebrities are full of different meaning reflecting such as demographic (age, gender) and lifestyle types, thus making it evident that celebrities convey not one but a variety of meaning. The cultural meanings that are connected with the celebrity will be transferred to the endorsed product/brand (Brierley, 1995). Mc Cracker explains this meaning transfer model in 3 stages. 


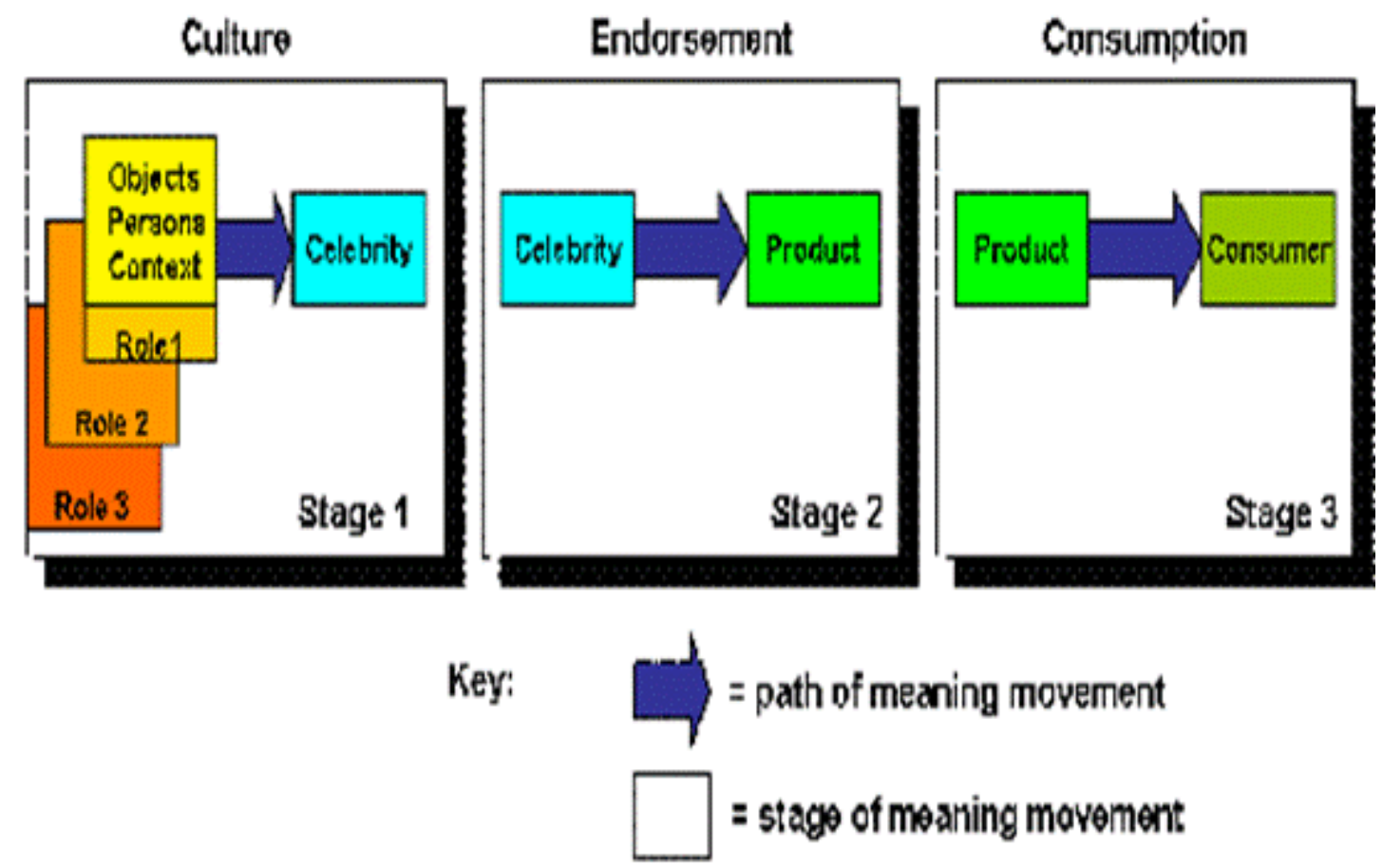

First, the meaning associated with the famous persons makes them the endorser to the product or brand. Thus, the meanings attributed to the celebrity become associated with the brand in the consumers. Secondly, in the consumption process, the customer acquires the brands meaning.

The third stage of the model explicitly shows the importance of the consumer's role in the process of endorsing brands. For example, Beyonce Knowles as a celebrity, has acquired a cultural meaning of beauty, elegance, attitude, sophistication and charisma. This meaning is then transferred to Pepsi, when she signed a promotional deal with Pepsi, which included appearances on TV commercials, radio and internet advertisements, as well as in-store promotional material. She has also signed a range of commercial deals for beauty care products and perfumes.

3. Match up hypothesis: The match-up hypothesis specifically suggests that the effectiveness depends on the existence of a "fit" between the celebrity and endorsed brand (Till and Buster, 1998: Khatri, 2006). The model emphasizes that the physical attractiveness of a celebrity endorser will enhance evaluations of the products 
characteristics only if the characteristics of the product "match-up" with the image conveyed by the celebrity. Marketers must match the product or company's image to the features of the target market, and the personality of the celebrity, in order to establish effective messages and the determinant of the match between celebrity and brand depends on the degree of perceived association between brand (brand name, attributes) and celebrity image (Khatri, 2006; Okorie, 2010).

\section{Celebrity Endorsement and Brand Communication}

McCracken (1998: 16) has reasoned that celebrity endorser as "any individual who enjoys public cognition and who uses this cognition on behalf of a consumer by appearing wit in an advertisement". Moreover, celebrity is used as testimonial, endorsement, actor or spokesperson by the firm. Research has demonstrated that celebrity endorsement affects consumers' feelings in general and it could affect the attitude of consumers towards the advertisement and brands too. This could result in enhancing of purchase intentions and as a result enhancing of sales. In other words, the use of celebrity endorsement helps to increase the recall value of the brand; this is why the use of celebrities in mainstream advertising is a common marketing communication strategy.

Firms endorse celebrity for a variety of reasons; it might be the life experience of the celebrity that fits with the advertising message or the endorser's high appeal with the firm's consumer target group. Okorie (2011) citing Cooper et al (2005) notes that all firms must be aware of some of the important aspects in the use of celebrity endorsement as discussed below:

- Consistency and long-term commitment: As with branding, companies should try to maintain consistency between the endorser and the brand to establish a strong personality and identity. More importantly, companies should view celebrity endorsements as long-term strategic decisions affecting the brand.

- Three prerequisites to selecting celebrities: Before signing on celebrities to endorse their brands, companies need to ensure that they meet three basic prerequisites, namely the endorser should be attractive, have a positive image in 
the society, and be perceived as having the necessary knowledge (although it might be difficult for a celebrity to meet all three prerequisites)

- Celebrity-brand match: Consistent with the principles discussed earlier, companies should ensure a match between the brand being endorsed and the endorser so that the endorsements are able to strongly influence the thought processes of consumers and create a positive perception of the brand.

- Constant monitoring: Companies should monitor the behavior, conduct and public image of the endorser continuously to minimize any potential negative publicity. One of the most effective ways to do this is to ensure that celebrity endorsement contracts are effectively drafted, keeping in mind any such negative events.

- Selecting unique endorsers: Companies should try to bring on board those celebrities who do not endorse competitors' products or other quite different products, so that there is a clear transfer of personality and identity between the endorser and the brand.

- Timing: As celebrities command a high price tag, companies should be on the constant lookout for emerging celebrities who show some promise and potential and sign them on in their formative years if possible to ensure a win-win situation.

- Brand over endorser: When celebrities are used to endorse brands, one obvious result could be the potential overshadowing of the brand by the celebrity. Companies should ensure that this does not happen by formulating advertising collaterals and other communications.

- Celebrity endorsement is just a channel: Companies must realize that having a celebrity endorsing a brand is not a goal in itself; rather it is one part of the communication mix that falls under the broader category of sponsorship marketing. 


\section{Functional and Dysfunctional effect of Celebrity Endorsement}

From a brand communication perspective, celebrity endorsement simply stipulates that the value associated with the celebrity is transferred to the brand and therefore help create an image that can be easily referred by consumers. Consequently by association, the brand can very quickly establish the creditability, recognition and increase brand equity.

The use of celebrity endorsement has several functional effects in brand communication. One of such functional effect is that it helps to maintain consumer attention and recall. Studies in celebrity endorsement research has revealed that customers are more likely to choose goods and services endorsed by celebrities than those without such endorsements(Okorie \& Aderogba, 2011) and celebrities help advertisements to carve a niche in a competitive environment, thus re-positioning the brand in the market (Sherman, 1995). Brand communication experts believe that using popular celebrity can affect consumers feeling and their purchase intention (Belch\& Belch, 2001). Ohanian's(1991) study on how the perceived image of a celebrity endorser affected the consumer's intention to purchase found that "only the perceived expertise of the celebrities was a significant factor explaining the respondents intention to purchase (Ohanian, 1991). O’Mahony and Meenaghan (1997), supported Ohanian's (1991) findings, they concluded that source characteristics with the greatest impact on the consumer's intention to purchase were those of credibility and expertise. This study also supports many academic works in this area. In addition, O'Mahony and Meenaghan (1997-98) found out that consumer response to endorsement messages was also linked to relatedness. This supports previous finding relating to athletics and sporting products. Moreover, it can be generalized to other celebrities including musicians and actors. O'Mahony and Meenaghan confirmed that consumers expected congruity between the celebrity endorsers' perceived images and type of products they endorse.

In addition, many scholars have argued that celebrity endorsement is effective due to the influential personalities of the celebrities. Assael (1984) suggests that celebrity advertising is effective because of its ability to tap into consumers' symbolic association 
to aspiration reference groups provides points of comparison through which the consumers may evaluate attitudes and behavior (Kemins, 1990). In other words, celebrity endorsement gives a brand a touch of glamour and the hope a famous face will provide added appeal and name recognition in a crowded market.

Another major benefit of using celebrity endorsement is that it can provide testimony for a product or service, particularly when the product has contributed to their celebrity. The more familiar an endorser, the more likely consumers are to buy the endorsed products (Miciak \& Shanklin, 1994). For example, Michael Jordan endorsed Nike, he uses various products of Nike when he trains and plays basketball, the endorsement improved the sales of Nike shoes in the United States and across the world. Also, a new brand can benefit greatly if a celebrity endorses it. It can attract the customers' attention and inquisitiveness to see what product is being endorsed. Research has shown consumers have a higher level of message recall for products that are endorsed by celebrities. For example, when Tu Face Idibia, a popular musician in Nigeria endorsed Airtel (a telecommunication service provider), a lot of people were attracted to their products and services.

However, there are many pitfalls associated with such endorsers. The brand could be negatively affected if the endorsements work against the brand. The reputation of the celebrity may derogate after he/she has endorsed the product: For example, Pepsi Cola's suffered with three tarnished celebrities - Mike Tyson, Madonna, and Michael Jackson. Since the behavior of the celebrities reflects on the brand, celebrity endorsers may at times become liabilities to the brands they endorse.

The vampire effect is one of the drawbacks in the use of celebrity endorsement in brand communication. This terminology refers to when a celebrity overshadows the brand. If there is no congruency between the celebrity and the brand, then the audience will remember the celebrity and not the brand. Khatri (2006) has also observed that there are chances that the celebrity is remembered more than a brand. He further explained that a cyber media research study reveals that $80 \%$ of the respondents approached for research remembered 
the celebrity but could not recall the brand being endorsed. For example, Chrysler aborted the advert with Celine Dion whose television commercial appearances only produced remarkable sales for the singer and not for the Pacifica car she advertised.

Many companies have financially suffered from the inconsistency in the professional popularity of the use of celebrities in endorsements: The celebrity may lose his or her popularity due to some lapse in professional performances. The 2003 Cricket World Cup threw up the Shane Warne incident, which caught Pepsi off guard. With the Australian cricketer testing positive for consuming banned substances and his subsequent withdrawal from the event, bang in the middle of the event, PepsiCo - the presenting sponsor of the World Cup 2003 - found itself on an uneasy wicket. Another challenge in the use of celebrity endorsement is the issue of multi brand endorsements by the same celebrity, which usually lead to overexposure. The novelty of a celebrity endorsement gets diluted if he does too many advertisements. This may be termed as commoditization of celebrities, who are willing to endorse anything for lots of money.

Firms usually have the problem when celebrities endorse one brand and use or patronize another brand. Most celebrities endorse brands due to monetary benefit they get from companies or firms; they are most times not loyal consumers to the endorsed brands. Sainsbury's encountered a problem with Catherina Zeta Jones, whom the company used for its recipe advertisements, when she was caught shopping in Tesco. A similar case happened with Britney Spears, who endorsed Pepsi and was repeatedly caught drinking another brand of Coca Cola on tape (Khatri, 2006).

One important pitfall in the celebrity endorsement is the mismatch between the celebrity and the image of the brand: Celebrities manifest a certain qualities for the audience. It is pivotal that there is an association between the character of the celebrity and the image of the brand. Each celebrity portrays a broad range of meanings, involving a specific personality and lifestyle. Brad Pitt, for example, is perceived as a tough, intense and modern man associated with the upper middle class. The personality of Desmond Elliot, a 
Nigerian movie artist, is best characterized as the perfect gentleman, whereas Omotola Jolade has the image of the 'good girl'. The use of Nkem Owoh, a male in the Harpic advert was a mismatch. As a norm in Nigeria, men do not clean toilets at home, since it is regarded as part of the domestic duties of a woman. Hence, the target audience to promote any toilet cleaning products is women. The use of the celebrity was hinged on outstanding success recorded as a Nollywood star, hence Harpic felt his popularity would effectively promote the brand and tremendously boost sales. They must have realized that using him was a wrong move as women considered it as a mere advertorial propaganda to make them buy the product. Bukky Wright, took over which got the attention of the audience. On the other hand, the impact Akin (Chinedu Ikedezie) and Pawpaw (Osita Iheme) made in promoting OK Sweets would not have been the same if an adult looking celebrity had taken a shot at it. Children regard the duo as Children stars to whom they can relate with, though naive about their real ages.

\section{Conclusion}

Celebrity endorsement is a common marketing communication strategy used to promote goods and services in the society. The use of celebrity endorsement as a brand strategy has its merits and demerits to organizational management and productivity. Against the backdrop of the match up hypothesis and transfer of meaning model, there should be proper selection in the choice of celebrity in the use of celebrity endorsement. In addition, an organization must be sensitive to know when to sign an endorsement contract and when to exit from such contract. Furthermore, the use of celebrity endorsement as a functional approach in brand communication becomes successful when the organization has invested in planning, research and brand monitoring. Also, the use of celebrity endorsement must be accompanied by a powerful idea, effective and impeccable positioning to promote the brand in an excellent light. 


\section{References}

Assael, H.(1984). Consumer behavior and market action. Boston, Massachusetts: Kent Publishing Company

Belch, G. and Belch, M.(2001).Advertising and promotion :An intergrated marketing communication.New York, USA: McGraw Hill

Khatri, A. (2006). Celebrity Endorsement: A strategic promotion perspective. India Media Studies. 1 (1)

Kulkarni, S. and Gaulkar, S.(2005). Impact of celebrity endorsement on overall brands. Retrieved on 2nd May 2008 from http://www.celebritiesnetwork.com

Mc Cracker, G. (1989), Who is the celebrity endorser? Cultural Foundatiers of the endorsement Process, Journal of Consumer Research, 16(3), 310-321.

Ohanian, R.(1990). Construction and validation of a scale to measure celebrity endorsers' perceived expertise, trustworthiness, and attractiveness. Journal of Advertising

Ohanian, R. (1991), The Impact of Celebrity spokespersons” Perceived Image on Consumers' Intention to purchase, Journal of advertising Research, 31(1),46-53.

Okorie, N. (2010). Celebrity advertising and its effect on brand loyalty. Interdisciplinary Journal of contemporary research in business, 1(4), 72-85

Okorie $\mathrm{N}$ and Aderogba, A. (2011). The role of celebrity advertising on brand patronage. International Journal of Research in Computer Application and Management, $1(1), 27-34$.

O’Mahony, S. \& Meenaghan, T.(1997). The impact of celebrity on consumers. Irish Market Review

Menon, M. \& Louis, E. (2005). Celebrity Advertising: An Assessment of Its Relative Effectiveness. Retrieved on 2nd May 2008 from http://www.ask.com

Solomon, R .(2002), Conumser Behaviour: Buying, Having and Being, $5^{\text {th }}$ ed., New Jersey: Prentice Hall

Till, Brian D. and Michael, B. (1998),’Matching Products with Endorser: Attractiveness Versus Expertise," Journal of Consumer Markeing, 15(6), 576-58 
White, R.(2000).Advertising. Cambridge, Britain: Pearson Education ltd

Zikmund. G. \& D’Amico .(2002). Marketing.New York, USA:McGraw Hill Publishing lt 